
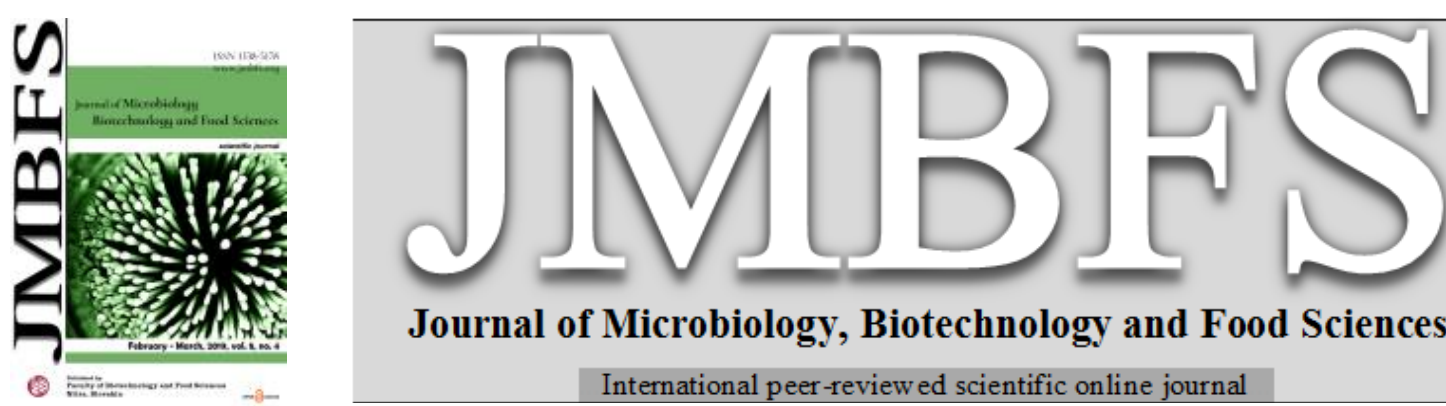

Journal of Microbiology, Biotechnology and Food Sciences

International peer-review ed scientific online journal

\title{
THE DEVELOPMENT, PURIFICATION AND CHARACTERIZATION OF ANTI- VITELLOGENIN ANTIBODIES RAISED IN HENS (GALLUS GALLUS DOMESTICUS) AGAINST TILAPIA (OREOCHROMIS NILOTICUS) VITELLOGENIN PROTEIN
}

\section{Jairo Caza ${ }^{1,2}$, Rodolfo Fernández ${ }^{1}$, Marbel Torres Arias ${ }^{2}$, Daysi Muñoz ${ }^{1}$, Juan Ortiz Tirado ${ }^{*}$, Bangeppagari Manjunatha ${ }^{1,3}$, Sikandar I. Mulla and Rajesh R. Kundapur ${ }^{5}$}

\author{
Address(es): \\ ${ }^{1}$ Department of Life Sciences, Laboratory of Water Resources and Aquaculture, Universidad de las Fuerzas Armadas-ESPE, Sangolquí - P.O.BOX: 171-5-231B, \\ Ecuador, South América. \\ ${ }^{2}$ Inmunology laboratory, Biotechnology Engineering, Universidad de las Fuerzas Armadas-ESPE, Sangolquí- P.O.BOX: 171-5-231B, Ecuador, South América. \\ ${ }^{3}$ Center for Biofluid and Biomimic Research, Pohang University of Science and Technology (POSTECH), Pohang - 37673, South Korea. \\ ${ }^{4}$ Division of Biotechnology, Chonbuk National University, Iksan, Republic of Korea. \\ ${ }^{5}$ Department of Zoology, University of Pune, Pune, India.
}

*Corresponding author: jcortiz@espe.edu.ec

doi: $10.15414 / j m b f s .2019 .8 .5 .1165-1168$

\section{ARTICLE INFO}

Received 15. 10. 2018

Revised 15. 12. 2018

Accepted 29. 12. 2018

Published 1. 4. 2019

Regular article

OPEN $\partial_{\text {ACCESS }}$

\begin{abstract}
This study was conducted to induce, isolate and characterize and determine the role of Vitellogenin (Vtg) which is used as a biomarker of environmental quality and steroidogenesis in oviparous organisms. We have purified Vtg from male adult tilapia scientifically known as Oreochromis niloticus previously treated with estradiol $5 \mu \mathrm{g} / \mathrm{g}$ body weight (BW). By using ion exchange chromatography Vtg was purified from blood plasma yielding $1.13 \mathrm{mg} \mathrm{Vtg} / \mathrm{ml}$. Subsequently, Lohmann Brown hens were immunized at a 125 and $100 \mu \mathrm{g}$ $\mathrm{Vtg} / \mathrm{ml}$, including three antigen treatments of booster doses of 75 and $50 \mu \mathrm{g} \mathrm{Vtg} / \mathrm{ml}$, respectively. At day 30 post-immunization, posture eggs were collected, we have successfully optimized the extraction of anti-VtgIgY antibody. The purified anti-VtgIgY was validated with SDS-PAGE, detecting heavy and light chains of $70 \mathrm{kDa}$ and $30 \mathrm{kDa}$, respectively. Further, we have developed ELISA using antiVtgIgY. To estimate the Vtg specificity, commercial anti-Vtg antibodies of dorada (Sparusaurata) were used and validated for tilapia by Western Blot. Detection of the Vtg monomer was at a dilution of 1/2000 IgY primary antibody. The antibodies thus obtained through the conventional techniques of production and validation of IgY antibodies for Vtg of tilapia demonstrate that they are viable under local conditions, can be successfully used for programs of environmental monitoring and reproduction control in oviparous species.
\end{abstract}

Keywords: Oreochromis niloticus, Vitellogenin, IgY, Western Blot, ELISA

\section{INTRODUCTION}

In fish, the incorporation of Vtg into the oocyte is a fundamental process for ovarian growth and for successful reproduction. These processes are related to oocyte growth through the incorporation of precursor proteins such as Vtg, lowdensity lipoproteins, vitamins, mRNA and other molecules in fish (Babin et al., 2007). Vtg is a complex high molecular weight phosphoglycoprotein that binds calcium and is synthesized in liver hepatocytes under 17 $\beta$-estradiol (E2) action by the interaction with intracellular receptors alpha type $(\operatorname{ER} \alpha)$ (Patiño and Sulivan, 2002). Follicle stimulating hormone (FSH) stimulates the expression of P450 aromatase which catalyzes the transformation of testosterone into E2 and promotes the incorporation of Vtg into oocytes in fish (Monserrat, 2004). The genes for Vtg are highly conserved and their number depends on the species and it generates multiple forms of specific Vtg species, with a different role in vitellogenesis periods, oocyte maturation and subsequent embryonic development (Carnevalli et al., 1999; Berg et al., 2004).

Tilapia is a biological model in asynchronous fish, which has three Vtg isoforms. The third isoform is Vtgc and homologous to zebrafish (Danio rerio) and identified by the loss of phosvitin and also in tilapia, the Vtg A isoform is a highest molecular weight with $210 \mathrm{kDa}$ (Davis et al., 2007). Vtg plasma measurement could provide parameters indicative of oocyte quality, or presence of endocrine disruptors in aquatic environments, with a high probability to bind to ER $\alpha$ intracellular receptors. The concentrations of Vtg can be estimated by immuno-enzymatic assays with polyclonal IgY birds antibody (Oliver et al., 2015). The IgY antibody has the ability to bind the specific sites of proteins, in response to a foreign stimulus and wide recognition of different epitopes of the same biomarker (Guzmán et al., 2003; Denslow, 1999). In this context, the IgY antibody production technology offers versatile advantages compared to mammalian $\mathrm{IgG}$, where the developmental methods are non-invasive, high immunogenicity for phylogenetically conserved proteins, and lack of crossreactions in assays immuno-enzymes (Carlander, 2002).

The aim of this study is to develop anti-Vtg antibodies in hens against tilapia Vtg protein which can generate useful and transferable information to fish industry in South America in general and Ecuador in specific, with a focus on the sustainable management of reproduction in oviparous species and the assurance of quality in aquatic environments.

\section{MATERIALS AND METHODS}

\section{Biological samples}

For induction of Vtg in the fish, synthetic estradiol (Sigma, USA) was used at a dose of $5 \mu \mathrm{g} / \mathrm{g}$ BW in 13 males of gray tilapia $(150 \mathrm{~g} \pm 10)$. From day 8 postinoculation, blood collection and plasma collection were performed at $3000 \mathrm{rpm}$ for 10 minutes at $4^{\circ} \mathrm{C}$. Plasma samples were preserved with protease inhibitors (PMSF) at $-80^{\circ} \mathrm{C}$ for further analysis (Denslow et al., 1999). The animals samples are used for the eggs of immunized hens, which were carried out in compliance with standards biosafety handling, the protocol was not approved by the bioethics committee because this organism experimental procedures were under construction at the University. This experiment was conducted by the experts in handling of experimental animals which carried out their postgraduate studies in Europe.

\section{Purification of Vtg antigen}

The Vtg was purified from blood plasma by using Sartobind MA Q-15 anion exchange columns (Sartorius, Germany). Previously a 1: 4 plasma (plasma: buffer) dilution was performed, and transferred through $0.22 \mu \mathrm{m}$ membrane 
filters. Subsequently, $\mathrm{NaCl}$ concentration gradients of $0.27 ; 0.33 ; 0.37 ; 0.40 \mathrm{M}$, used for later elution in the corresponding columns (Shi et al., 2003). The best concentration fraction of Vtg $(100 \mathrm{kDa})$ thus obtained was centrifuged at 2000 rpm for 4 minutes at $4^{\circ} \mathrm{C}$ and aliquoted into Millipore tubes (100000 MWCO) for further analysis.

\section{Validation of the Vtg (antigen) by SDS PAGE}

The protein concentration of Vtg was quantified with the Qubit ${ }^{\circledR}$ Protein Assay kit (Invitrogen, USA). The presence of Vtg was validated by SDS PAGE on $8 \%$ polyacrylamide gel. For this process the sample was previously mixed with the loading buffer $5 \mathrm{X}$ [glycerol 20\%; $63 \mathrm{mM}$ TRIS-HCl $\mathrm{pH} 6.8 ; 2 \%$ SDS, $0.1 \%$ Bromophenol Blue; $\beta$-mercaptoethanol] in a 1: 1 ratio, the sample was finally denatured at $95^{\circ} \mathrm{C}$ for 10 minutes and cooled to $4^{\circ} \mathrm{C}$ for 10 minutes. A molecular weight marker (Novex) was used to determine the protein size. The electrophoretic run was performed at $110 \mathrm{~V}$ for 30 minutes. The separation ge was then stained with Coomassie R-250 for 30 minutes, constant stirring at room temperature. The gel was destained until the clear bands were visible.

\section{Immunization of chickens against Vtg}

Adult laying hens $(n=4)$ of Lohmann Brown (Gallus gallus domesticus) variety were immunized intramuscularly with two doses of purified Vtg. Treatment 'A' includes the first inoculation of $125 \mu \mathrm{g} \mathrm{Vtg} / \mathrm{ml}$ and three post inoculation booster dose of $75 \mu \mathrm{gVtg} / \mathrm{ml}$ for every 8 days. Treatment ' $\mathrm{B}$ ' includes the inoculation of $100 \mu \mathrm{gVtg} / \mathrm{ml}$ and three post inoculation booster dose of $50 \mu \mathrm{gVtg} / \mathrm{ml}$ for every 8 days. The first dose in both treatments were being mixed with complete Freund's adjuvant, and the subsequent booster doses with incomplete Freund's adjuvan (1:1 ratio) were added and final inoculation volume was adjusted to $1 \mathrm{ml}$. The birds were maintained with $23 \%$ protein balanced feed with spirulina and vitamin E throughout the experiment, and with the respective biosafety measures. For the IgY antibody extraction and purification process, the eggs were collected every day before and after immunization. For this trial, 5 eggs were selected from each treatment, and three eggs from the control group were also selected.

\section{Extraction and purification of anti-Vtg antibodies}

At 32 days of post-immunization eggs were selected and separated from each treatment. Prior washing and disinfecting each egg, only egg yolk, which was diluted in $60 \mathrm{ml}$ of $0.1 \%$ pectin of $\mathrm{pH} 4$ was kept in shaker with continuous stirring for 8 hours and the temperature was maintained to $4{ }^{\circ} \mathrm{C}$. The mixture thus obtained whose $\mathrm{pH}$ adjusted to 5.2 and centrifuged at $10200 \mathrm{rpm}$ the resulted supernatant was collected. The temperature throughout the isolation process was maintained to $4{ }^{\circ} \mathrm{C}$ until otherwise mentioned. For isolation of $\mathrm{IgY}$ antibodies, $35 \%$ ammonium sulfate, was used and added to the supernatant with constant agitation for 8 hours. The mixture was centrifuged at $10200 \mathrm{rpm}$ for 25 minutes at $4{ }^{\circ} \mathrm{C}$ and the resulting pellet was suspended in $0.025 \mathrm{M}$ phosphate buffer $(\mathrm{pH}$ 8.0). Subsequently, the purification of the IgY antibodies was carried out by ion exchange chromatography (Shimizu et al., 1988). For further purification and in order to get rid of salts the eluted fractions were subjected to ultrafiltration which was performed in Millipore tubes. . Five previously purified IgY fractions were quantified for total protein by the bicinchoninic acid method, BCA Protein-Assay Kit, and SDS -PAGE.

\section{Indirect sensitivity test by ELISA}

Fractions of purified Vtg at a concentration of 5 and $10 \mu \mathrm{g} / \mathrm{ml}$ were diluted in citrate buffer $\mathrm{pH} 8$, and a volume of $100 \mu \mathrm{l}$ were prepared added to wells of Nunc-ImmunoMaxisorp F8 plates (Nalge Nunc, Denmark) and incubated over night at $4{ }^{\circ} \mathrm{C}$. Plates were washed 5 times with TBS-T. Antigen unbound sites were blocked with $200 \mu$ of blocking solution and incubated for 1 hour at $37^{\circ} \mathrm{C}$. The plate was washed for 5 times. Antibody concentrations of IgY-anti Vtg used were at a concentration of 1,2 and $4 \mu \mathrm{g} / \mathrm{ml}$ mixed with pre-diluted in blocking solution made up the volume $100 \mu \mathrm{l}$ and added to the wells. Incubation was formed for one hour at $37{ }^{\circ} \mathrm{C}$. After 5 times wash the antibody labeling was performed with $100 \mu \mathrm{l}$ of anti-chicken HRP conjugate diluted in blocking solution (1:10000), incubation for one hour at $37^{\circ} \mathrm{C}$ and followed by series of washes. Finally, $100 \mu \mathrm{l}$ of 3,3',5,5'-Tetramethylbenzidine (TMB) in developing solution containing dimethylsulfoxide (DMSO); phosphate-citrate buffer $\mathrm{pH} 5$ $1 \%$ hydrogen peroxide was added and incubated for 30 minutes. The reaction was stopped by adding ( $2 \mathrm{M}$ sulfuric acid. A spectrophotometer (Biorad) was used and the absorbance was measured at $450 \mathrm{~nm}$.

\section{Western blotting}

After gel electrophoresis, the gel and the nitrocellulose membrane were transferred to western blotting unit. For the transfer process, the following conditions were used: $100 \mathrm{~V}$, for 1 hour. To verify protein transfer, with the nitrocellulose membrane was stained with reversible stain i.e. Ponceau red for 5 minutes at room temperature, and constant stirring; destained with distilled water until the colored bands of the protein were observed. Immunostaining was done by blocking the nitrocellulose membrane for one hour and 30 minutes at room temperature with constant stirring, immediately washed with $5 \mathrm{~mL}$ wash buffer $5 \mathrm{ml}$ of diluted $\mathrm{IgY}$-anti Vtg primary antibody (1:2000) was added in blocking solution and incubated for overnight at $4{ }^{\circ} \mathrm{C}$. The membrane was washed, and then incubated with $5 \mathrm{~mL}$ of the diluted anti-chicken HRP secondary antibody (1:5000) in blocking solution for 2 hours under constant stirring at room temperature. The blot was developed using $0.5 \mathrm{~mL}$ of hydrogen peroxide solution containing $0.5 \mathrm{~mL}$ of luminol substrate (LumiGLO, BIORAD) for 1 minute at room temperature and the blot was read using C-Digit Scanner.

\section{RESULTS}

\section{Purification and quantification of Tilapia Vtg protein}

Protein levels in plasma detected statistical differences between treatments and control $(\mathrm{p}<0.05 ; \mathrm{n}=13)$, with $30.57 \pm 3.94 \mathrm{mg} / \mathrm{ml}$ in estradiol treatment, and 20 $\pm 4.00 \mathrm{mg} / \mathrm{ml}$ in control. The variation coefficient for induced males was $12.9 \%$. Induced samples in an elution at $0.37 \mathrm{M} \mathrm{NaCl}$ detected $1.13 \mathrm{mgVtg} / \mathrm{ml}$ with an approximate molecular mass of $220 \mathrm{kDa}$. (Figure 1).

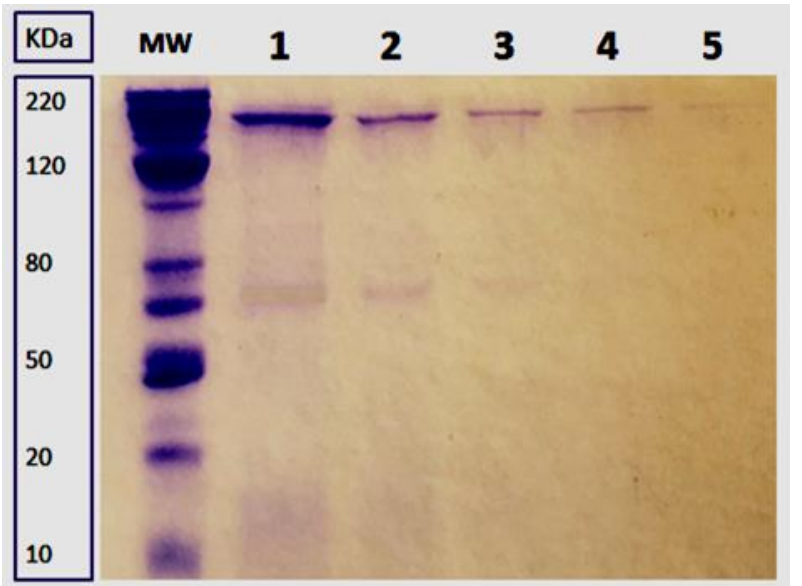

Figure $18 \%$ SDS-PAGE gel. Identification of purified Vtg by ion exchange chromatography. MW, molecular weight marker; $(1=\mathrm{Vtg}$ at $1.13 \mathrm{mg} / \mathrm{ml} ; 2=$ Vtg at $563 \mu \mathrm{g} / \mathrm{ml} ; 3=\mathrm{Vtg}$ at $281 \mu \mathrm{g} / \mathrm{ml} ; 4=\mathrm{Vtg}$ at $140 \mu \mathrm{g} / \mathrm{ml} ; 5=\mathrm{Vtg}$ at $70 \mu \mathrm{g} / \mathrm{ml})$.

\section{Purification of IgY by ion exchange chromatography}

IgY antibodies thus obtained after purification were $5.2 \mathrm{mg} / \mathrm{ml}$ against the treatment $\mathrm{A}$ and $2.96 \mathrm{mg} / \mathrm{ml}$ against the treatment $\mathrm{B}$. The calibration curve for BCA quantification maintained an $\mathrm{r}^{2}=0.9962$. Two bands could be seen in each lane of purified IgY samples. The first band (heavy chain) was located at $70 \mathrm{kDa}$ and the second band (light chain) at $30 \mathrm{KDa}$ (Figure 2).

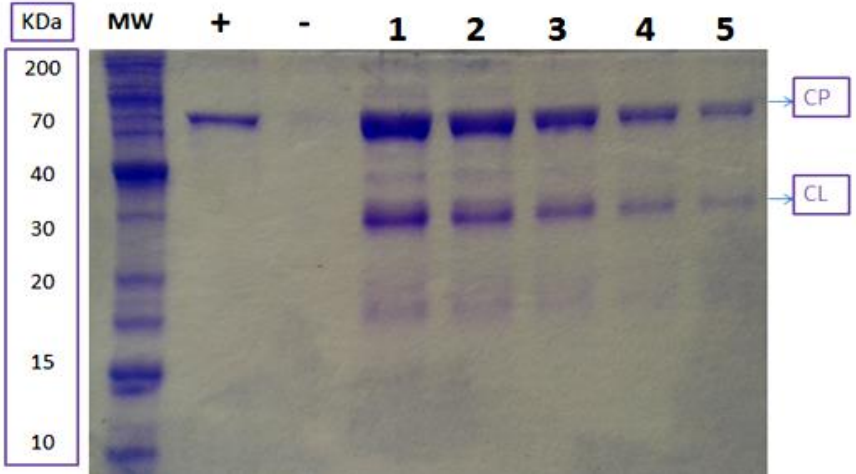

Figure 2 SDS-PAGE 10\% purified IgY by ion exchange chromatography. (MW= molecular weight marker; '十'= Commercial anti-Vtg IgG; ' $-'=$ reagent control; 1 $5=$ purified samples of IgY; $\mathrm{CP}=$ heavy chain; $\mathrm{CL}=$ light chain).

\section{Evaluation of anti-Vtg antibody through indirect ELISA}

The enzyme-linked immunosorbent assay (ELISA) for purified antibodies obtained in treatment groups ' $\mathrm{A}$ ' and ' $\mathrm{B}$ ' showed higher absorbance at concentrations of 1 and $2 \mu \mathrm{g} / \mathrm{ml}$. As reference the commercial rabbit anti-Vtg antibody (Cayman, USA) were used which was developed against tilapia Vtg. The standard deviation for all ' $\mathrm{A}$ ' and ' $\mathrm{B}$ ' treatments were 0.18 and 0.21 , respectively, with a coefficient of variation between the trials were 3,5 and $6.9 \%$. (Figure $3 \mathrm{~A}$ and 3B). 
Identification IgY (TB) by ELISAi

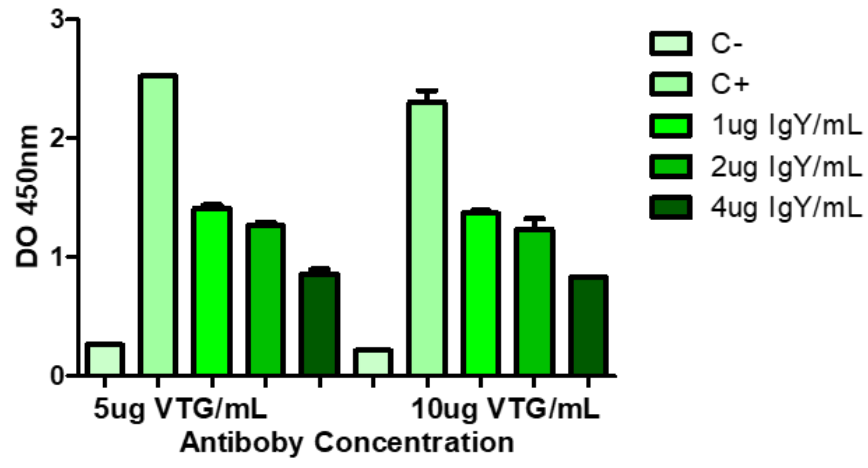

Identification IgY (TA) by ELISAi

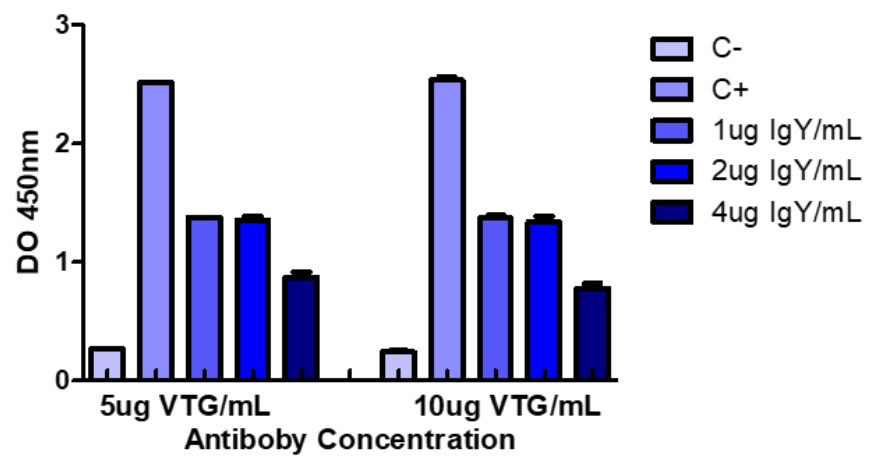

Figure 3 Absorbance values of the indirect ELISA at different concentrations of IgY antibody; $\mathrm{A}=\mathrm{Ig} \mathrm{A}$ antibodies purified from treatment $\mathrm{A}$ subjected to immunoabsorbent reaction; $\mathrm{B}=$ purified $\mathrm{IgY}$ antibodies of treatment $\mathrm{B}$ undergoing immunoabsorbent reaction; $\mathrm{SD}=$ Standard deviation.

\section{The study of specificity of anti-Vtg antibodies through Western Blot:}

An optimal dilution of the anti-Vtg of 1:2000 gave very good results. The specificity of the IgY antibody was optimal by detecting the Vtg monomer at a concentration of $140 \mu \mathrm{g} / \mathrm{ml}$ and at a band height of $220 \mathrm{kDa}$ (Figure 4).

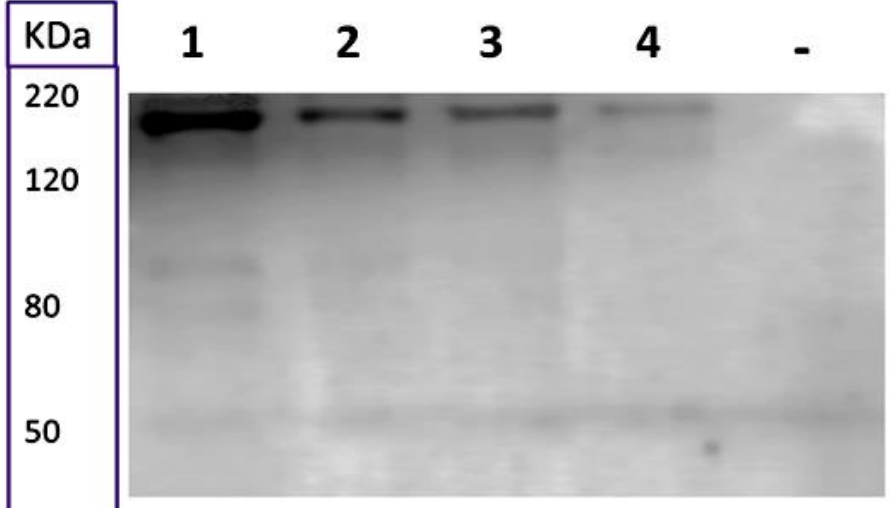

Figure 4 Western Blot of Vtg against purified $\operatorname{IgY}$ antibodies. ( $1=\mathrm{Vtg}$ at a concentration of $1127 \mu \mathrm{g} / \mathrm{ml}$ of antigen; $2=\mathrm{Vtg}$ at $563 \mu \mathrm{g} / \mathrm{ml} ; 3=\mathrm{Vtg}$ at 281 $\mu \mathrm{g} / \mathrm{ml} ; 4=$ Vtg at $140 \mu \mathrm{g} / \mathrm{ml} ;{ }^{\prime}-'=$ negative control).

\section{DISCUSSION}

The induction of Vtg in fish through inoculation of synthetic estradiol (E2), is widely used and successful in breeding and environmental impact studies in aquatic ecosystems (Buerano et al., 1995; Denslow, 1999; Schafhauser-Smith et al., 2002; Sawaguchi et al., 2005). The concentration of $5 \mu \mathrm{g} \mathrm{E} 2 / \mathrm{g}$ live weight according to Denslow (1999), differs greatly from that used by Buerano et al., (1995) of $20 \mu \mathrm{g} / \mathrm{g}$ live weight, for the amount of $\mathrm{Vtg}$ produced per individual The concentration obtained in the present study was sufficient for the production of $\mathrm{IgY}$ in laying hens, and this is given by the cellular response at low doses and at maximum yield. The ability of cellular response depends on many factors but mainly on the self-regulation of the number of inter- and intra-cellular receptors for the synthesis and secretion of certain molecules (Ortiz et al., 2015).
The purification of Vtg in teleost's highlights the technique of gel filtration chromatography, with a flow rate of $0.4 \mathrm{ml} / \mathrm{min}$ (Fazielawanie et al., 2013), ion exchanger and ion exchange chromatography with flow rates 0,3 to $0.2 \mathrm{ml} / \mathrm{min}$ (Leonardi et al., 2010) and precipitation variants with $\mathrm{MgCl} 2$ and FPLC (Fast protein liquid chromatography) in Salvelinusalpinus (Berg et al., 2004). All these techniques make the procedure very lengthy and expensive compared to the Sartobind Q15 ion exchange membranes, which have a high capacity of separation of molecules, with a flow rate of $5 \mathrm{ml} / \mathrm{min}$ and a maximum elution time of 10 minutes (Shi et al., 2003). On the other hand, the quantification of purified Vtg is comparable with the studies of Shi et al. 2003 with $1,067 \mathrm{mg}$ $\mathrm{Vtg} / \mathrm{ml}$ and applying the same methodology. It is noteworthy that ultrafiltration to remove excess $\mathrm{NaCl}$ allowed obtaining a higher concentration of Vtg (Maltais et al., 2009).

Identification of Vtg by SDS-PAGE under reducing and denaturing conditions; is preponderant to obtain highly readable bands, and to visualize a band above 200 kDa. Similar results were obtained by Buerano et al., (1995) in the identification of Vtg in Oreochromis niloticus (185KDa), Swart et al., (2009) in mossambic tilapia females weighing $200 \mathrm{KDa}$. Other authors such as Fukada et al., (2003) purified carp Vtg (Cyprinus carpio) weighing $150 \mathrm{KDa}$, Shimizu et al., (2002) in common medaka (Oryzias latipes) at $220 \mathrm{KDa}$. This allows inferring the specificity of the Vtg according to the species, given its conformation and molecular weight, which includes physiological factors such as age and feeding of the specimen (Babin et al., 2007)

The treatments proposed for immunization generated anti-VtgIgY antibodies in gray tilapia, where the antigens diluted in Freund's adjuvant allowed to enhance the immunogenicity status in laying hens. (Denslow et al., 1999; Li et al., 2017), proposed the production of polyclonal antisera against Vtg, which presents high immunogenicity in hyperimmunized rabbits or mice at the first dose of $100 \mu \mathrm{g} / \mathrm{ml}$ and reinforcements of $50 \mu \mathrm{g} / \mathrm{ml}$. Similar concentrations of antibodies were obtained by Buerano et al., (1995) in gray tilapia with inoculum ranges of $0.2-1$ $\mathrm{mg} / \mathrm{ml}$. Tada et al., (2004) produced polyclonal anti-Vtg antibodies of Chinese turtle (Chinemysreevesii) at inoculation doses of $500 \mu \mathrm{g} / \mathrm{ml}$. The concentrations obtained in the different treatments $5.21 \mathrm{mg} / \mathrm{ml}$ and $2.96 \mathrm{mg} / \mathrm{ml}$ at 32 days postimmunization are maximal IgY concentrations. It should be noted that the peak IgY antibody concentration can occur within 30 days after the first immunization and maintained until day 70 (Gassmann et al., 1990).

The enzyme-linked immunosorbent assay (ELISA) was required to confirm the presence of purified $\mathrm{IgG}$ antibody against Vtg, which would show antigenantibody reaction specificity (Cevallos et al., 2017). The use of the anti-Vtg commercial anti-Vtg goldfish (Sparus aurata) antibody with cross-reactivity against Vtg of Oreochromis niloticus was important for the validation of the enzymatic assay. This reaction recorded a maximum optical density of 2.59 to $450 \mathrm{~nm}$. Treatment A presented the best absorbance result at 1.42 with a Vtg concentration as the antigen of $10 \mu \mathrm{g} / \mathrm{ml}$ and an $\mathrm{IgY}$ concentration of $2 \mu \mathrm{g} / \mathrm{ml}$. On the other hand, treatment B exhibited the best absorbance at 1.41 under conditions of $5 \mu \mathrm{g} / \mathrm{ml} \mathrm{Vtg}$ and $2 \mu \mathrm{g} / \mathrm{ml} \mathrm{IgY} \mathrm{as} \mathrm{antigen} \mathrm{and} \mathrm{primary} \mathrm{antibody}$ respectively. These results are comparable to those obtained by Swart and Pool (2009), who standardized an ELISA for Vtg detection of Oreochromis mossambicus. Similarly, Sotiropoulou et al., (2012) have also tested the antigenantibody binding at a concentration of $1 \mu \mathrm{g} / \mathrm{ml} \mathrm{IgY.} \mathrm{This} \mathrm{result} \mathrm{is} \mathrm{comparable}$ with the present study in ranges of sensitivity and concentration of anti-VtgIgY from 1 to $4 \mu \mathrm{g} / \mathrm{ml}$. The specificity of anti-Vtg at a dilution of 1:2000 was validated by Western Blot where the Vtg monomer was detected in dilution ranges from $140 \mu \mathrm{g} / \mathrm{ml}$ and with a molecular weight of approximately $220 \mathrm{kDa}$. These data were earlier documented by Ortiz et al., (2015) using a 1:1500 dilution of primary anti-Vtg antibodies.

\section{CONCLUSION}

In the present study, we have shown that the Vtg is a phosphoglycoprotein circulating in fish, is an environmental bio-indicator in aquatic ecosystems and a molecule of quality reproduction in oviparous species. Vtg is a species specific molecule, therefore the production of polyclonal antibodies IgY is an alternative tool for this species. The production of anti-Vtg in laying hens, is a non-invasive technology, highly sensitive, and a relatively low and cost effective. This tool could be used as effective mechanism for environmental conservation programs with many endemic oviparous fishes that are unknown about their reproduction cycle in Ecuadorian rivers.

Acknowledgements: This work was supported by grants received from the Universidad de las Fuerzas Armadas -ESPE (project: PIC-037-2012) and the authors would like to thank, Dr. César Ulloa and Dr. Jorge Ron for the critical review of this manuscript; Agronomical career IASA - ESPE and especially to Mario Ortiz for providing the lab space and birds for the present study. The coauthor (Bangeppagari Manjunatha) is greatful for the Korean Research Fellowship Program received through the National Research Foundation of Korea (NRF) funded by the Ministry of Science and ICT 


\section{REFERENCES}

Babin, P., Cerdà, J., Lubzens, E. (2007). The fish oocyte: From basic studies to biotechnological applications. Dordrecht: Springer.

Berg, H., Modig, C., Olsson, P.-E. (2004). 17beta-estradiol induced vitellogenesis is inhibited by cortisol at the post-transcriptional level in Arctic char (Salvelinusalpinus). Reproductive Biology and Endocrinology, 1-10. https://doi.org/10.1186/1477-7827-2-62

Buerano, C., Inaba, K., Natividad, F., Morisawa, M. (1995). Vitellogenins of Oreochromisniloticus: Identification, isolation, and biochemical and immunochemical characterization. The Journal of Experimental Zoology, 59-69. https://doi.org/10.1002/jez.1402730108

Carlander, D. (2002) Avian IgY antibody. Uppsala University.

Cevallos, W., Calvopiña, M., Nipáz, V., Vicente-Santiago, B., López, J., Fernández, P., Guevara, Á., Muro, A. (2017). Enzime-linked immunosorbent assay for diagnosis of Amphimerus spp. liver fluke infection in Humans. MemoriasInstituto Oswaldo Cruz, 1-6. https://doi.org/10.1590/007402760160426

Denslow, N. (1999). Vitellogenin as a biomarker of exposure for estrogen or estrogen mimics. Ecotoxicology, 385-398.

Dias, W., Tambourgi, D. (2010. IgY: A promising antibody for use in immunodiagnostic and in immunotherapy. Veterinary Immunology and Immunopathology, 173-180. https://doi.org/10.1016/j.vetimm.2009.12.011

Fazielawanie, N., Siraj, S., Harmin, S., Ina-Salwany, M. (2013). Isolation and partial characterization of Asian sea bass (Latescalcarifer) Vitellogenin. Fish Physiol Biochem, 191-200. https://doi.org/10.1007/s10695-012-9690-5

Fukada, H., Fujiwara, Y., Takahashi, T., Hiramatsu, N. (2003). Carp (Cyprinuscarpio) vitellogenin: Purification and development of a simultaneus chemiluminescent immunoassay. Comp. Biochem. Physiol., 615-623.

Gassmann, M., Thommes, P., Weiser, T., Hubscher, U. (1990). Efficient production of chicken egg yolk antibodies against a conserved mammalian protein. The FASEB Journal, 2528-2532.

Leonardi, M., Vera, J., Tarifeño, E., Puchi, M., Morín, V. (2010). Vitellogenin of the Chilean flounder Paralichthysadspersus as a biomarker of endocrine disruption along the marine coast of the South Pacific. Part I: induction, purification, and identification. Fish Physiol. Biochem, 757-765. https://doi.org/10.1007/s10695-009-9350-6

Li, X., Jing, K., Wang, X., Li, Y., Zhang, M., Li, Z., Xu, L., Wang, L., Xu, Y. (2016). Protective effects of chicken egg yolk antibody (IgY) agains experimental Vibrio splendidus infection in the sea cumber (Apostichopusjaponicus). Fish \& Sellfish Immunology. https://doi.org/10.1016/j.fsi.2015.11.024

Maltais, D., Roy, R. (2009). Purification and partial characterization of vitellogenin from shorthead redhorse (Moxostomamacrolepidotum) and cooper redhorse (Moxostomahubbsi) and detection in plasma and mucus with a heterologous antibody. Fish Physiol Biochem, 241-254.

Oliver, C., Valenzuela, K., Silva, H., Haro, R., Cortés, M., Sandoval, R., Pontigo, J., Álvarez, C., Figueroa, J., Avendaño, R., Troncoso, J., Yáñez, A. (2015) Effectiveness of egg yolk immunoglobulin against the intracellular salmonid pathogen Piscirickettsiasalmonis. Journal Applied Microbiology, 365-376. https://doi.org/10.1111/jam.12857

Ortiz, J., Muñoz, D., Valladares, L., Manjunatha, B., Kundapur, R. (2015)

Modulation of gonadal steroids production by tilapia pituitary extract: An evaluation through in-vitro and in-vivo studies. International Journal of Pharmacy and Pharmaceutical Sciences, 127-130.

Patiño, R., Sullivan, C. (2002). Ovarian follicle growth, maturation, and ovulation in teleost fish. Fish Physiology and Biochemistry, 57-70. https://doi.org/10.1023/A:1023311613987

Sawaguchi, S., Koya, Y., Yoshizaki, N., Ohkubo, N., Andoh, T., Hiramatsu, N., Matsubara, T. (2005). Multiple vitellogenins (Vgs) in mosquitofish (Gambusiaaffinis): Identification and characterization of three functional Vgs genes and their circulating and yolk protein products. Biology of Reproduction, 1045-1060. https://doi.org/10.1095/biolreprod.104.037895

Schafhauser-Smith, D., Benfey, T. (2002). The purification and development of a quantitative enzyme linked immunosorbent assay (ELISA) for the measurement of vitellogenin in diploid and triploid brook trout (Salvelinus fontinalis). Fish Physiology and Biochemistry, 287-298. https://doi.org/10.1023/A:101508531

Shi, G., Shao, J., Jiang, G., Wang, Q., Lu, Y., Liu, J., \& Liu, J. (2003). Membrane chromatographic method for the rapid purification of vitellogenin from fish plasma. Journal of Chromatography B, 361-368.

Shimizu, M., Fitzsimmons, R., Nakai, S. (1988). Anti-E. Coli immunoglobulin Y isolated from egg yolk of immunized chickens as a potential food ingredient. Journal of Food Science, 1360-1366.

Shimizu, M., Fujiwara, Y., Fukada, H., Hara, A. (2002). Purification and identification of a second form of vitellogenin from ascites of medaka (Oryziaslatipes) treated with estrogen. Journal Experimental Zoology, 726-735.

Stifani, S., Le Men, f., Nunez, J., Schneider, W. (1990). Regulation of oogenesis: the piscine receptor for vitellogenin. Biochimicaet Biophysica Acta, 271-279. 